\title{
The Effect of Jatropha Curcas Seed Meal on Growth Performance and Internal Organs Development and Lesions in Broiler Chickens
}

Review

\section{Author(s)}

\section{Barros CR'}

Rodrigues MAM"

Nunes FM"II

Kasuya MCMiv

Luz JMR daIV

Alves A"

Ferreira LMM"

Pinheiro V"

Mourão JL"

Universidade de Trás-os-Montes e Alto Douro, Department of Animal Science Vila Real, Portugal

" CECAV - Universidade de Trás-os-Montes e Alto Douro, Department of Animal Science, Vila Real, Portugal

III CQ - Universidade de Trás-os-Montes e Alto Douro, Department of Chemistry, Vila Real, Portugal

IV Universidade Federal de Viçosa, Department of Microbiology, Campus Universitário, Viçosa, MG, Brazil

\section{-Mail Address}

Corresponding author e-mail address José L Mourão

Universidade de Trás-os-Montes e Alto Douro, Department of Animal Science, 5000-801 Vila Real, Portugal. E-mail: jlmourao@utad.pt

\section{Eeywords}

Broiler, Jatropha curcas, phorbol ester, toxicity.

\section{ABSTRACT}

The meal of Jatropha curcas (JCM) seed is a by-product of the biofuel industry and may potentially to be used as animal feed. However, its toxicity has prevented its utilization in animal nutrition mainly due to its high concentration of phorbol esters. This study was conducted to evaluate the effects of the dietary inclusion of JCM on the growth performance, feed digestibility and internal organs development of broilers. Thirty two 48-d-old Ross 308 broiler chickens housed in 16 pens (2 birds/pen) were used in this study. Birds were randomly allocated to dietary treatments comprising four JCM levels (negative control, 25, 50, or $100 \mathrm{~g} \mathrm{JCM} / \mathrm{kg}$ of diet) for four weeks. Results showed that increasing levels of JCM had a negative impact on broiler performance, reducing live weight, weight gain, and feed intake. Treatments led to a decrease of the relative weight of testis and spleen, and to an increase in heart relative weight. In broilers fed diets containing JCM, the testis were atrophic, presenting reduced size of the seminiferous tubule, which were small and lined within active sertoli cells and rare spermatogonia. This study illustrates the negative impact of diets containing JCM on broiler performance and JCM pathological effects on several organs.

\section{INTRODUCTION}

The animal feed industry has faced serious challenges as the demand for feeds and raw materials is expected to escalate in order to cope with increasing demand for animal food products. Furthermore, there is also a growing awareness that due to the competition between humans and the animal industry, the existing resources should be drastically reduced. These and other potential drawbacks may hamper the development of poultry production industry. In this global scenario, research aiming at studying new alternative feedstuffs is particularly important. Nevertheless, an information gap is clearly identified for studies where the impact of such feedstuffs is evaluated, especially those containing toxic compounds.

Jatropha curcas meal (JCM), obtained after oil extraction, has been characterized as a potential animal feedstuff due to its high crude protein (CP) content (Makkar \& Becker, 1999; Makkar et al., 2008) and high levels of essential amino acids, except for lysine (Makkar et al., 1998; Rakshit \& Bhagya, 2008). However, its toxicity, mainly attributed to phorbol esters (PE), has hindered its use as animal feed (Makkar et al., 1997). Studies evaluating its utilization in animal nutrition have been performed using different animal models and plant materials. Negative effects have been observed in goats (Gadir et al., 2003; Katole et al., 2013), sheep (Katole et al., 2011), pigs (Chivandi et al., 2006), and fish (Becker \& Makkar 1998; Kumar et al., 2010). El-Badwi \& Adam (1992) and El-Badwi et al. (1995) reported mortality and severe pathological 
Barros CR, Rodrigues MAM, Nunes FM, Kasuya MCM, Luz JMR da, Alves A, Ferreira LMM, Pinheiro V, Mourão JL
The Effect of Jatropha Curcas Seed Meal on Growth Performance and Internal Organs Development and Lesions in Broiler Chickens changes in Brown Hisex chicks. These results indicate that PE may have a wide range of toxicological effects at different levels of intake and that animal species may also respond differently. Thus, it is important to characterize the effects of adding different levels of these compounds in broilers diets to evaluate their growth performance and health.

In this study, different levels of $\operatorname{JCM}(25,50$ and $100 \mathrm{~g} / \mathrm{kg}$ ) were incorporated in broiler diets in order to evaluate their effects on growth performance and on internal organs development and lesions.

\section{MATERIALS AND METHODS}

\section{Animals and diets}

A total of 32 Ross male broilers chickens with 48 days of age were randomly allocated in sixteen floor pens ( 2 birds per pen). The pens were located in a temperature-controlled room, which was daily adjusted to the recommended values, according to standard management practices. Birds were acquired from a local hatchery and were fed a commercial prestarter diet until the beginning of the trial.

Seeds of Jatropha curcas acquired in Mozambique were used to obtain the JCM. Whole seeds were pressed with a Komet expeller press CA59G-3 (IBG Monforts Oekotec, Mönchengladbach, Germany) to extract the oil. The obtained JCM was milled to1-mm particle size using a hammer mill. Four dietary treatments were obtained by adding to a basal diet 0, 25, 50 and 100 $\mathrm{g}$ of JCM/kg (diets $\mathrm{J}_{0} \mathrm{~J}_{2.5}, \mathrm{~J}_{5}, \mathrm{~J}_{10}$ respectively; Table 1 ). The basal diet was based on corn and soybean meal and was formulated to meet or exceed the NRC (1994) recommendations for all nutrients. All the diets were in mash form.

\section{Experimental design}

In the beginning of the growth trial birds (2557 $\pm 215 \mathrm{~g}$ ) were randomly assigned so that each experimental diet $\left(J_{0}, J_{2.5}, J_{5}\right.$ and $\left.J_{10}\right)$ was randomly distributed to 16 pens, totaling eight birds and four pens per treatment, in a room under natural daylight conditions and temperature of 18 to $23^{\circ} \mathrm{C}$. Birds were allowed ad libitum access to the experimental diets and water during the experimental period (48 to 76 days of age). Body weight, body weight gain and feed intake were recorded weekly per pen.

All trials were carried out in accordance with the Portuguese law (Portaria $n^{\circ} 1005 / 92$ ) on animal care in experimental research.
Table 1 - Ingredient composition (\%, as fed) of the experimental diets

\begin{tabular}{lcccc}
\hline & \multicolumn{4}{c}{ Diet } \\
\cline { 2 - 5 } & $J_{0}$ & $J_{2.5}$ & $J_{5}$ & $J_{10}$ \\
\hline Ingredients (\%) & 0.00 & 2.50 & 5.00 & 10.00 \\
\hline Jatropha curcas meal & 58.90 & 57.43 & 55.93 & 52.93 \\
\hline Corn & 24.15 & 23.45 & 22.85 & 21.65 \\
\hline Soybean meal 47\% & 13.22 & 12.92 & 12.52 & 11.72 \\
\hline Whole soybean & 0.23 & 0.23 & 0.23 & 0.23 \\
\hline Salt & 0.79 & 0.79 & 0.79 & 0.79 \\
\hline Calcium carbonate & 1.14 & 1.14 & 1.14 & 1.14 \\
\hline Dicalcium phosphate & 0.10 & 0.10 & 0.10 & 0.10 \\
\hline Choline 75\% & 0.25 & 0.25 & 0.25 & 0.25 \\
\hline DL-Methionine & 0.70 & 0.70 & 0.70 & 0.70 \\
\hline L-Lysine & 0.50 & 0.50 & 0.50 & 0.50 \\
\hline Mineral and vitamin premix & & & & \\
\hline Analyzed composition (\%) & 18.40 & 18.10 & 18.30 & 19.00 \\
\hline Crude protein & 3.90 & 4.20 & 4.60 & 5.20 \\
\hline Crude fat & 2.80 & 3.30 & 4.30 & 5.80 \\
\hline Crude fiber & 0.00 & 0.02 & 0.03 & 0.06 \\
\hline Phorbol esters & & & & \\
\hline Estimated composition (\%) & 36.90 & 36.00 & 35.00 & 33.20 \\
\hline Starch & 3.50 & 3.50 & 3.40 & 3.30 \\
\hline Free sugar & 2990 & 2929 & 2867 & 2742 \\
\hline Metabolizable energy (kcal/kg) & 2990 \\
\hline
\end{tabular}

'Mineral-vitamin premix provided the following per kilogram of feed: 11,000 IU of vitamin A, 2,150 IU of vitamin D3, $25 \mathrm{mg}$ of vitamin $\mathrm{E}, 1 \mathrm{mg}$ of vitamin $\mathrm{K}, 5 \mathrm{mg}$ of riboflavin, $20 \mathrm{mg}$ of niacin, $8 \mathrm{mg}$ of pantothenic acid, $1 \mathrm{mg}$ of folic acid, $0.1 \mathrm{mg}$ of biotin, $200 \mathrm{mg}$ of choline, $0.012 \mathrm{mg}$ of vitamin B12, $50 \mathrm{mg}$ of $\mathrm{Mn}, 40 \mathrm{mg}$ of $\mathrm{Zn}, 5 \mathrm{mg}$ of $\mathrm{Cu}, 0.1 \mathrm{mg}$ of Se.

\section{Organ evaluation}

At 80 days of age all birds were euthanized by cervical dislocation for organ evaluation. After euthanasia, liver, kidneys, small and large intestines, testis, spleen, and heart were carefully removed, weighed and examined for gross and microscopic changes. The gross abnormalities observed in proventriculus tissues were submitted to histopathological examination by optical microscopy. The tissues were fixed in 10\% neutral formalin. Tissue samples were processed in a Shandon Hipercenter XP automated tissue processor (Thermo Fisher Scientific, Waltham, USA) and embedded in paraffin wax. Three micrometer paraffin sections were cut on a Biocut 2035 microtome (Leica Microsystems, Buffalo Grove, USA) and stained with hematoxylin and eosin.

\section{Chemical Analysis}

Ground $(1 \mathrm{~mm})$ samples of the experimental diets were analyzed for dry matter (DM), ash, total $N$ as Kjeldahl $\mathrm{N}$ and fat contents. The DM content was determined in a forced-ventilation oven at $60{ }^{\circ} \mathrm{C}$ for $72 \mathrm{~h}$. Ash was determined using standard procedures 
Barros CR, Rodrigues MAM, Nunes FM, Kasuya MCM, Luz JMR da, Alves A, Ferreira LMM, Pinheiro V, Mourão JL

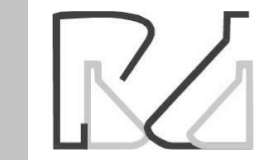

The Effect of Jatropha Curcas Seed Meal on Growth Performance and Internal Organs Development and Lesions in Broiler Chickens

and these effects were more pronounced when the diets with 50 and $100 \mathrm{~g} \mathrm{JCM} / \mathrm{kg}$ were fed $\left(J_{5}\right.$ and $J_{10}$ ). Overall, the birds fed diets $J_{2.5}$ and $J_{5}$ presented $31 \%$ and $54 \%$ lower weight gain compared with the control group, respectively, while animals fed the diet with highest level of JCM inclusion $\left(J_{10}\right)$ presented severe weight loss during the trial. Diets with JCM also decreased feed intake $(p<0.001)$. Diet $J_{2.5}$ decreased feed intake by $29 \%$, diet $J_{5}$ reduced it by $38 \%$ and diet $J_{10}$ by $65 \%$. The observed negative effects could be partially explained by the reduction of the metabolizable energy content of the diets containing JCM and the increase in fiber content (Table 1). Even though it is expected that deficient energy diets can negatively affect animal performance, the decrease of the estimated metabolizable energy content of the diets $(-2.0 \%,-4.1 \%$ and $-8.3 \%$, respectively for $J_{2.5}, J_{5}$ and $J_{10}$ ) could not have influenced growth performance results to the observed extent. Negative effects of fiber on poultry performance have been reported by several authors (Jørgensen et al., 1996; Sklan et al., 2003; Jiménez-Moreno et al., 2011), but it has also been argued that this response depends, amongst other factors, on the type and amount of fiber in the diets and the age of animals (Mateos et al., 2012). In the present experiment, dietary crude fiber levels were below the limit of $70 \mathrm{~g} / \mathrm{kg}$ maximum incorporation level normally suggested by poultry producers and feed manufacturers, and birds were already 8 weeks old when the trials begun. In this way,

Table 2 - Effect of diets on adjusted treatment means of broiler body weight, weight gain, and feed intake

\begin{tabular}{|c|c|c|c|c|c|c|}
\hline & \multicolumn{4}{|c|}{ Diet } & \multirow{2}{*}{ SEM } & \multirow{2}{*}{$P$-value } \\
\hline & $\mathrm{J}_{0}$ & $\mathrm{~J}_{2.5}$ & $\mathrm{~J}_{5}$ & $J_{10}$ & & \\
\hline \multicolumn{7}{|c|}{ Body weight (g) } \\
\hline 48 days & 2470.0 & 2603.8 & 2552.5 & 2618.3 & 51.37 & 0.488 \\
\hline 55 days & $3022.5^{\mathrm{a}}$ & $2922.5^{a}$ & $2866.7^{a}$ & $2584.3^{b}$ & 49.08 & 0.001 \\
\hline 62 days & $3679.0^{a}$ & $3448.8^{a b}$ & $3258.6^{b}$ & $2593.1^{c}$ & 84.02 & $<0.001$ \\
\hline 69 days & $4416.2^{a}$ & $3923.1^{\text {ab }}$ & $3568.9^{b}$ & $2432.4^{c}$ & 160.23 & $<0.001$ \\
\hline 76 days & $4923.5^{a}$ & $4179.7^{a b}$ & $3625.9^{b}$ & $2316.1^{c}$ & 193.41 & $<0.001$ \\
\hline \multicolumn{7}{|c|}{ Weight gain (g/day) } \\
\hline 48-55 days & $66.5^{a}$ & $52.2^{\mathrm{ab}}$ & $44.2^{a}$ & $3.9^{b}$ & 7.02 & 0.001 \\
\hline 55-62 days & $93.8^{a}$ & $75.2^{\mathrm{ab}}$ & $56.0^{b}$ & $1.2^{c}$ & 7.29 & $<0.001$ \\
\hline 62-69 days & $105.5^{a}$ & $67.8^{\mathrm{ab}}$ & $44.3^{b}$ & $-21.6^{c}$ & 13.81 & 0.001 \\
\hline 69-76 days & $84.5^{a}$ & $42.8^{b}$ & $9.5^{b c}$ & $-19.4^{c}$ & 9.49 & $<0.001$ \\
\hline 48-76 days & $87.6^{a}$ & $60.1^{\mathrm{ab}}$ & $39.6^{b}$ & $-8.9^{c}$ & 7.14 & $<0.001$ \\
\hline \multicolumn{7}{|c|}{ Feed intake (g/day) } \\
\hline 48-55 days & $187.9^{a}$ & $182.4^{\mathrm{a}}$ & $158.9^{a}$ & $105.6^{b}$ & 9.10 & $<0.001$ \\
\hline 55-62 days & $254.4^{a}$ & $174.9^{b}$ & $170.8^{b}$ & $114.4^{b}$ & 17.91 & 0.004 \\
\hline 62-69 days & $321.2^{\mathrm{a}}$ & $202.1^{b}$ & $189.9^{b}$ & $84.9^{c}$ & 21.08 & $<0.001$ \\
\hline 69-76 days & $300.6^{a}$ & $192.7^{\mathrm{ab}}$ & $142.7^{\mathrm{bc}}$ & $76.2^{c}$ & 25.51 & 0.001 \\
\hline 48-76 days & $266.0^{a}$ & $188.0^{\mathrm{b}}$ & $165.6^{\mathrm{b}}$ & $95.3^{c}$ & 16.24 & $<0.001$ \\
\hline
\end{tabular}

a-c Means with different superscripts differ at $p<0.05$. 
Barros CR, Rodrigues MAM, Nunes FM, Kasuya MCM, Luz JMR da, Alves A, Ferreira LMM, Pinheiro V, Mourão JL

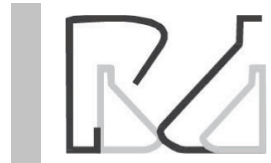

The Effect of Jatropha Curcas Seed Meal on Growth Performance and Internal Organs Development and Lesions in Broiler Chickens although some effects of fiber might be expected, growth performance data indicate that other factors have contributed to these results.

As stated before, PE are considered to be the main toxic component of JCM, limiting its use in animal feeding, and the adverse effects on animal performance and health observed in this experiment, due to the level of JCM inclusion in the diets, are consistent with the results presented by other authors. Nevertheless, these deleterious effects depend on the dose and on the vulnerability of the different animal species. Growth depression was observed by El-Badwi \& Adam (1992) and El-Badwi et al. (1992) when feeding Jatropha curcas seeds to Brown Hisex chicks at concentrations of 0.1 and $0.5 \%$. More recently, other authors have also reported reduced feed intake and growth in rats (Aregheore et al., 2003) fed diets containing JCM with final PE concentrations varying from 0.015 to $0.021 \%$. Our results indicate that broilers fed diets containing 0.03 to $0.06 \%$ of PE systematically presented lower performances compared with the control diet with no addition of JCM, during all the experimental periods (Table 2). The birds fed the diet with the highest PE concentration $(0.06 \%)$ immediately showed signs of growth depression in the first week of the trials and lost weight from the second experimental week onward. Although less evident, even the diets containing $0.02 \%$ of PE caused a decrease in body weight gain and feed intake. These results show that even at very low concentrations PE can cause severe effects on broilers.

It should be noted that although no deaths were recorded during these trials, signs of morbidity were evident in animals fed the diets $J_{5}$ and $J_{10}$. Nevertheless, clinical symptoms normally described as characteristic signs of intoxication by JCM such as diarrhea, dyspnea and hemorrhages (Makkar \& Becker, 1998) were not identified, suggesting that low levels of PE in diets will not cause severe clinical signs. Similar results were reported by Berenchtein et al. (2014) in an experiment conducted with pigs. These authors also did not observe typical signs of poisoning when animal were fed diets containing PE concentrations lower than $0.01 \%$. However, the dietary levels of JCM had a negative effect on body weight, average daily gain, and average daily feed intake. Therefore, threshold levels of PE in animals diets must be carefully evaluated as available data on animal toxicity has been basically obtained in trials using force-feeding of feed or its organic solvent/aqueous extracts (Li et al., 2010), and not in growth trials.

The experimental diets had no effect on the weight of liver or kidneys (Table 3 ). However, a trend $(p=0.0776)$ towards an increase in the length of the small intestine as a function of the level of JCM inclusion in the diets was observed. It is well known that intestinal weight and length maybe modified as a response to the diet (Bradford, 1996) and that changes in the amount and type of fiber increase the size of the small intestine (Jorgensen et al., 1996). Performance results of the broilers given diets with different levels of JCM inclusion clearly show a decrease in feed intake, and it seems that the birds had to readjust the development of their digestive tract in order to cope with the reduced amount of nutrients being absorbed. In the same way, the increased metabolic requirements of broilers may have caused increased cardiac output and heart enlargement, leading to the observed increase in heart weight $(p<0.05)$.

The detrimental effects of JCM inclusion in the diets, possibly due to the toxic effects of $\mathrm{PE}$, are evidenced by the decrease in spleen and testis relative weight (Table 3). Diet $J_{10}$ decreased the spleen and testis relative weights by $46 \%$ and $90 \%$, respectively. A wide range of biological effects, including tumor promotion and inflammation, are attributed to $\mathrm{PE}$, and these adverse effects are highly structure-specific (Baldini et al., 2012). Although lymphoid organ changes should be carefully interpreted (Haley et al., 2005), the observed decrease in spleen weight, associated with other effects such as weight loss and the observed alterations in the testis, may be attributed to severe toxicity. The histological examination of the testis reinforces the

Table 3 - Internal organ relative weight ( $\mathrm{g} / \mathrm{kg}$ live weight) and relative length of small intestine ( $\mathrm{cm} / \mathrm{kg}$ live weight) of broilers

\begin{tabular}{|c|c|c|c|c|c|c|}
\hline & & & & & & \\
\hline & $J_{0}$ & $\mathrm{~J}_{2.5}$ & $J_{5}$ & $J_{10}$ & SEM & $P$-value \\
\hline Liver & 14.78 & 15.70 & 15.58 & 14.27 & 0.535 & 0.805 \\
\hline Intestines & 40.96 & 42.78 & 47.98 & 54.39 & 1.907 & 0.078 \\
\hline Heart & $4.22^{\mathrm{b}}$ & $5.80^{a}$ & $5.59^{a}$ & $5.23^{\mathrm{ab}}$ & 0.211 & 0.014 \\
\hline Spleen & $0.92^{\circ}$ & $0.69^{a b}$ & $0.61^{b}$ & $0.50^{b}$ & 0.044 & 0.002 \\
\hline Kidneys & 4.51 & 4.96 & 4.60 & 3.98 & 0.131 & 0.093 \\
\hline Testis & $1.78^{\circ}$ & $0.23^{b}$ & $0.23^{b}$ & $0.18^{b}$ & 0.206 & 0.003 \\
\hline
\end{tabular}

a-b Means with different superscripts differ at $p<0.05$ 
Barros CR, Rodrigues MAM, Nunes FM, Kasuya MCM, Luz JMR da, Alves A, Ferreira LMM, Pinheiro V, Mourão JL

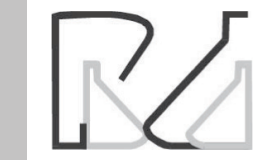

direct detrimental effect of Jatropha incorporation on the sexual development of the broilers (Figure 1). While the testis from control group were well developed, the testis of birds fed diets $J_{25}, J_{5}$ and $J_{10}$ were atrophic, with a decrease in the size of seminiferous tubules, which were small and lined with inactive Sertoli cells and rare spermatogonia. No significant lesions were observed in the heart, liver, kidney, spleen or lung tissues examined. Rakshit et al. (2008) fed different diets containing PE contents similar to the inclusion rates used in our study to rats, and although no statistical histological differences were observed in the vital organs, also identified minor changes in the seminiferous tubules of the testis. Furthermore, these authors also reported negative growth rates in the animals consuming diets with PE.

Therefore, although a wide range of detrimental biological effects are attributed to phorbol esters
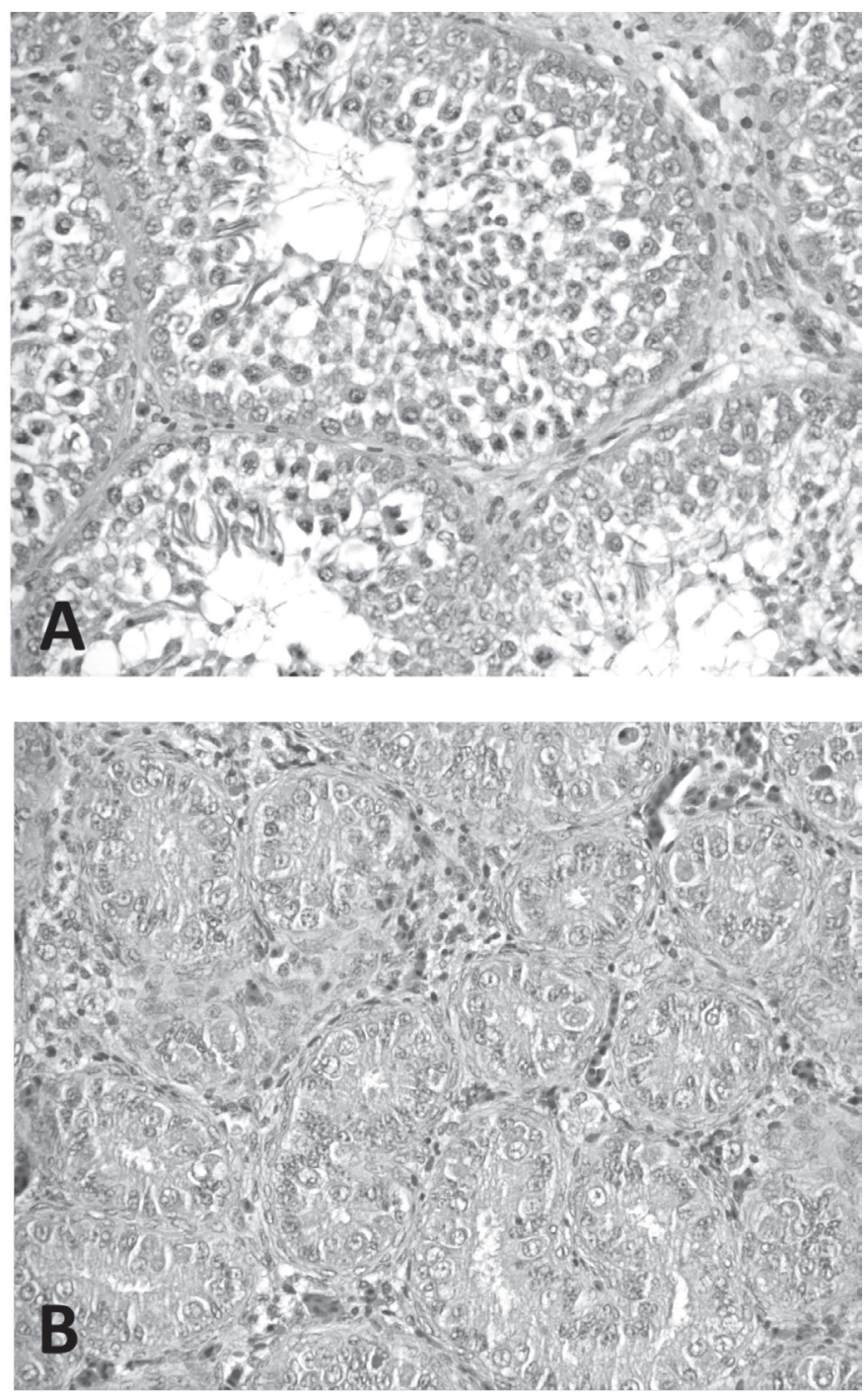

Figure 1 - Testis tissue of broilers fed diets $J_{0}(A)$ and $J_{10}(B)$.
The Effect of Jatropha Curcas Seed Meal on Growth Performance and Internal Organs Development and Lesions in Broiler Chickens

and their different derivatives, threshold levels should be carefully studied as toxicological studies may not reflect overall animal growth performance. For broiler diets, further studies are necessary to evaluate the inclusion level of Jatropha curcas meal, as even very low concentrations of phorbol esters seem to have negative effects on animal performance, as well as to determine the minimum inclusion level of Jatropha curcas meal that will require detoxification treatments.

\section{ACKNOWLEDGMENTS}

This work was supported by a research protocol financed by Galp Energia SGPS, SA, Portugal.

\section{REFERENCES}

AOAC International. Official Methods of Analysis of AOAC International. 15th ed. Washington: Association of Analytical Chemists; 1990.

Aregheore EM, Becker K,Makkar HPS. Detoxification of a toxic variety of Jatropha curcas using heat and chemical treatments, and preliminary nutritional evaluation with rats. South Pacific Journal of Natural Science 2003:21:50-56

Baldini M, Raranciuc S, Vischi M. Toxicity of Jatropha curcas L. as a biofuel crop and options for management. CAB Reviews 2012;7(42):1-13.

Becker K, Makkar HPS. Effects of phorbol esters in carp (Cyprinus carpio L.) Veterinary and Human Toxicology 1998;40(2):82-86

Berenchtein B, Abdalla AL, Paim T do Prado, Sbardella M, Louvandini H, Filho ALA, Dhanasekaran D, dos Santos PP. Effects of detoxified Jatropha curcas kernel meal in finishing pig diets on their performance, carcass traits, meat quality and intoxication. Livestock Science 2014;165:100103

Bedford MR. Interactions between ingested feed and the digestive system in poultry. Journal of Applied Poultry Research 1996;5(1):85-95.

Chivandi E, Erlwanger K, Makuza SM, Read JS, Mtimuni JP. Effect of dietary Jatropha curcas meal on percent packed cell volume, serum glucose, cholesterol and triglyceride concentration and alpha-amylase activity of weaned fattening pigs. Research Journal of Animal and Veterinary Sciences 2006;1(1):18-24.

El-Badwi SM, Adam SE. Toxic effects of low levels of dietary Jatropha curcasseed on brown hisex chicks. Veterinary and Human Toxicology 1992;34(2):112-115.

El-Badwi SM, Mousa HM, Adam SE, Hapke HJ. Response of brown hisex chicks to low levels of Jatropha curcas, Ricinus communis or thei mixture. Veterinary and Human Toxicology 1992; 34(4):304-306.

El-Badwi SM, Adam SE, Hapke HJ. Comparative toxicity of Ricinus Communis and Jatropha curcas in brown hisex chicks. Deutsche Tierärztliche Wochenschrift 1995;102(2):75-77.

Gadir WSA, Onsa TO, Ali WEM, El Badwi SMA, Adam SEI. Comparative toxicity of Croton macrostachys, Jatropha curcas and Piper abyssinica seeds in Nubian goats. Small Ruminant Research 2003;48(1):61-67.

Haley P, Perry R, Ennulat D, Frame S, Johnson C, Lapointe JM, et al. Best practice guideline for the routine pathology evaluation of the immune system. Toxicologic Pathology 2005;33(3):404-407. 
Barros CR, Rodrigues MAM, Nunes FM,

Kasuya MCM, Luz JMR da, Alves A,
Ferreira LMM, Pinheiro V, Mourão JL

Jiménez-Moreno E, Chamorro S, Frikha M, Safaa HM, Lázaro R, Mateos GC. Effects of increasing levels of pea hulls in the diet on productive performance, development of the gastrointestinal tract, and nutrient retention of broilers from one to eighteen days of age. Animal Feed Science and Technology 2011;168(1-2):100-112.

Jørgensen $\mathrm{H}$, Zhao XQ, Knudsen KEB, Eggum BO. The influence of dietary fibre source and level on the development of the gastrointestinal tract, digestibility and energy metabolism in broiler chickens. British Journal of Nutrition 1996;75(3):379-395.

Katole S, Saha SK, Das A, Sastry VRB, Lade MH, Prakash B. Nutrient intake, digestibility, and blood metabolites of goats fed diets containing processed jatropha meal. Tropical Animal Health and Production 2013;45(7):1563-1569.

Katole S, Saha SK, Sastry VRB, Lade MH, Prakash B. Intake, blood metabolites and hormonal profile in sheep fed processed Jatropha (Jatropha curcas) meal. Animal Feed Science and Technology 2011;170(1-2):21-26.

Kumar V, Makkar HPS, Becker K. Dietary inclusion of detoxified Jatropha curcas kernel meal: effects on growth performance and metabolic efficiency in common carp, Cyprinus carpio L. Fish Physiology and Biochemistry 2010;36(4):1159-1170.

Li C-Y, Devappa RK, Liu J-X, Lv J-M, Makkar HPS, Becker K. Toxicity of Jatropha curcas phorbol esters in mice. Food and Chemical Toxicology 2010;48(2):620-625

Makkar HPS, Aderibigbe AO, Becker K. Comparative evaluation of nontoxic and toxic varieties of Jatropha curcas for chemical composition, digestibility, protein degradability and toxic factors. Food Chemistry 1998;62(2):207-215

Makkar HPS, Becker K. Jatropha curcas toxicity: Identification of toxic principle(s). In: Garland T, Barr AC, editors. Toxic plants and other natural toxicants. New York: CAB International; 1998. p.554-558.
The Effect of Jatropha Curcas Seed Meal on Growth Performance and Internal Organs Development and Lesions in Broiler Chickens

Makkar HPS, Becker K. Nutritional studies on rats and fish (carp Cyprinus carpio) fed diets containing unheated and heated Jatropha curcas meal of a non-toxic provenance. Plant Foods for Human Nutrition 1999;53(3):183-192.

Makkar HPS, Francis G, Becker K. Protein concentrate from Jatropha curcas screw-pressed seed cake and toxic and antinutritional factors in protein concentrate. Journal of the Science of Food and Agriculture 2008;88(9):1542-1548.

Makkar HPS, Becker K, Sporer F, Wink M. Studies on Nutritive Potential and Toxic Constituents of Different Provenances of Jatropha curcas. Journal of Agricultural and Food Chemistry 1997;45(8):3512-3157.

Mateos GG, Jiménez-Moreno E, Serrano MP, Lázaro RP. Poultry response to high levels of dietary fiber sources varying in physical and chemical characteristics. Journal of Applied Poultry Research 2012;21(1):156174.

NRC - National Research Council. Nutrient Requirements of Poultry. 9th rev. ed. Washington: National Academic Press; 1994.

Rakshit KD, Bhagya S. Biochemical and nutritional evaluation of Jatropha protein isolate prepared by steam injection heating for reduction of toxic and antinutritional factors. Journal of the Science of Food and Agriculture 2008;88(5):911-919.

Rakshit KD, Darukeshwara J, Raj KR, Narasimhamurthy K, Saibaba P, Bhagya S. Toxicity studies of detoxified Jatropha meal (Jatropha curcas) in rats. Food and Chemical Toxicology 2008;46(12):3621-3625.

Sklan D, Smirnov A, Plavnik I. The effect of dietary fibre on the small intestines and apparent digestion in the turkey. British Poultry Science 2003:44(5):735-740. 